\title{
Intramedullary Spinal Capillary Hemangioma: Case Report
}

\section{Hemangioma capilar intramedular: relato de caso}

\author{
Leonardo Welling ${ }^{1} \quad$ Mariana S. Welling ${ }^{1}$ Eberval G. Figueiredo ${ }^{2}$ \\ 1 Universidade Estadual de Ponta Grossa, Ponta Grossa, Paraná, Brazil \\ 2 Universidade de São Paulo, São Paulo, São Paulo, Brazil \\ Address for correspondence Leonardo Welling, PhD, Universidade \\ Estadual de Ponta Grossa, Av. General Carlos Cavalcanti, 4748, \\ Uvaranas, Ponta Grossa, PR, 84030-900 Brazil \\ Arq Bras Neurocir 2017;36:125-127. \\ (e-mail: leonardowelling@yahoo.com.br).
}

\begin{abstract}
Capillary hemangiomas involving the neuraxis are very uncommon. In the spinal cord, they are located mainly intradural and extramedullary. To our knowledge, only four cases in conus medullaris have been previously described. In our case, a 46-year-old man was admitted with back pain, sphincter disturbances, as well as progressive weakness and numbness on the lower extremities. Magnetic resonance imaging revealed an undefined intramedullary lesion on the conus medullaris. The patient underwent microsurgery, which achieved complete removal. Histopathological diagnosis was compatible with capillary hemangioma. His postoperative course was uneventful and all symptoms, including bladder dysfunction clearly regressed. The treatment of

Keywords

- intramedullary

- spinal

- tumor

Resumo

Palavras-chave

- intramedular

- medula

- tumor intramedullary capillary hemangiomas is very critical in preventing unnecessary morbidity, providing accurate information with respect to prognosis, and establishes a regular outpatient follow-up. The natural history of this lesion involving the spinal cord is not well described, although they are common elsewhere in the body.

Hemangiomas capilares que envolvem o neuroeixo são raros. Quando localizados na coluna vertebral, geralmente são intradurais e extramedulares. Até a presente data somente 4 casos de hemangiomas no cone medular foram descritos. $O$ caso refere-se a um homem de 46 anos com dor lombar, alterações esfincterianas, fraqueza e parestesias em membros inferiores de evolução progressiva. Ressonância magnética demonstrou lesão no cone medular de aspecto indefinido. Submetido a remoção microcirúrgica completa. Histopatológico compatível com hemangioma capilar. O pósoperatório ocorreu sem intercorrências e houve recuperação dos déficits, inclusive da disfunção esfincteriana. O tratamento dessa lesão não deve acrescentar morbidade. A história natural dessa lesão na medula espinhal ainda não está definida, apesar de ser uma lesão comum em outras partes do organismo.
\end{abstract}

\section{Introduction}

Capillary hemangiomas involving the neuraxis are very uncommon. In the spinal cord, they are located mainly intradural and extramedullary. ${ }^{1}$ According to the literature, vascular lesions account for approximately $6 \%-7 \%$ of all intradural spinal tumors, although intramedullary capillary are extremely rare. $^{2}$ To our knowledge, only four cases in conus medullaris have been previously described since the earliest publication in $1987 .{ }^{3}$ received

August 1, 2015

accepted

October 7, 2015

published online

December 14, 2015
DOI https://doi.org/

10.1055/s-0035-1570100. ISSN 0103-5355.
Copyright $\odot 2017$ by Thieme Revinter

Publicações Ltda, Rio de Janeiro, Brazil
License terms

(요 (1) $\Theta \circledast$ 


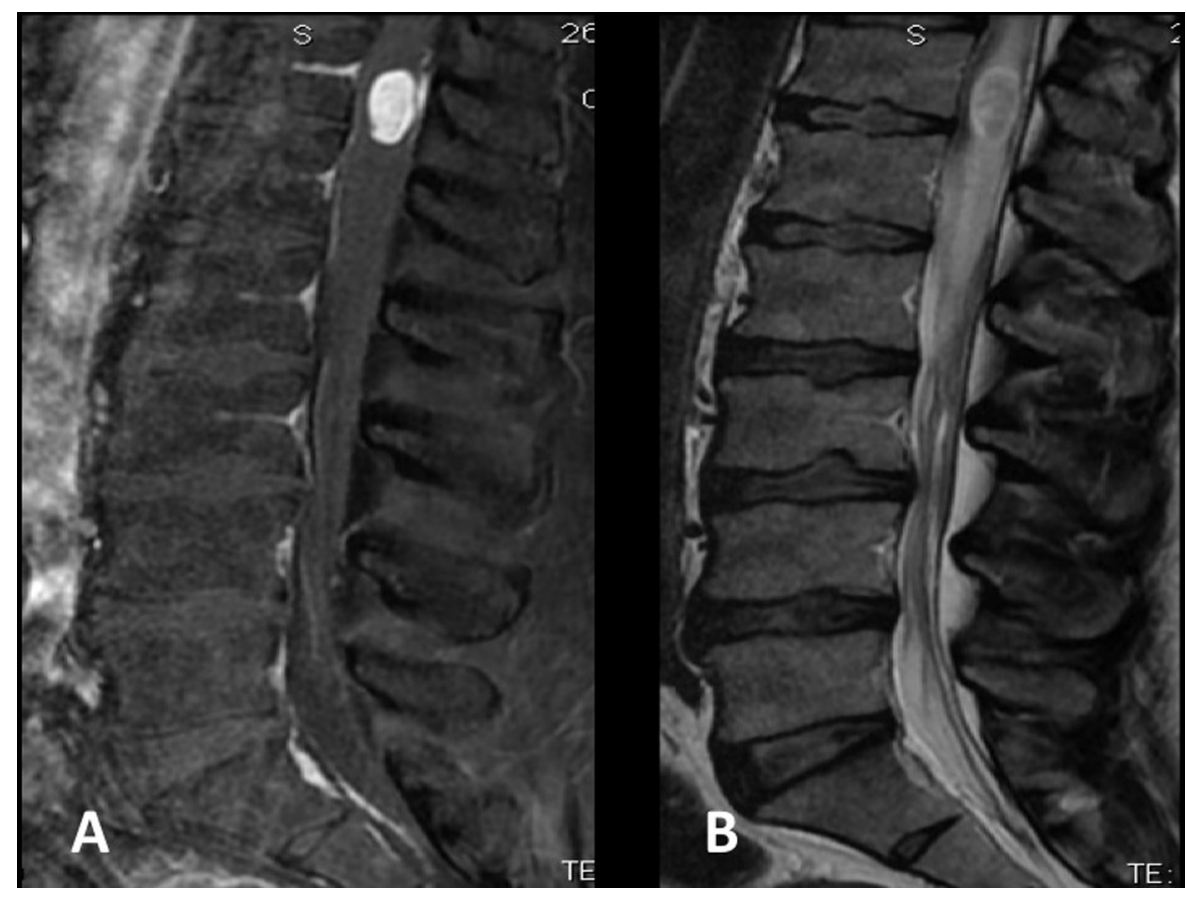

Fig. 1 MRI of the lumbar spine. The lesion was mildly hyperintense on T2-weighted images, with marked enhancement after contrast material injection.

\section{Case Report}

A 46-year-old man was admitted with intermittent back pain of 12 months' duration, which was intractable to medical treatment. The pain got worse and the patient presented with sphincter disturbances as well as progressive weakness and numbness on the lower extremities three months prior to his admission. A neurological examination showed a muscle power of Grade $4 / 5$ of the bilateral lower limbs. Magnetic resonance imaging (MRI) of the lumbar spine revealed an undefined intramedullary lesion on the conus medullaris. The lesion was $24 \mathrm{~mm}$ (height), $15 \mathrm{~mm}$ (anterior-posterior), $19 \mathrm{~mm}$ (latero-lateral) in size. The lesion was isointense on T1- weighted images and mildly hypertensive on T2-weighted images, with marked enhancement after contrast material injection (-Fig. 1A, 1B). The patient underwent microsurgery and

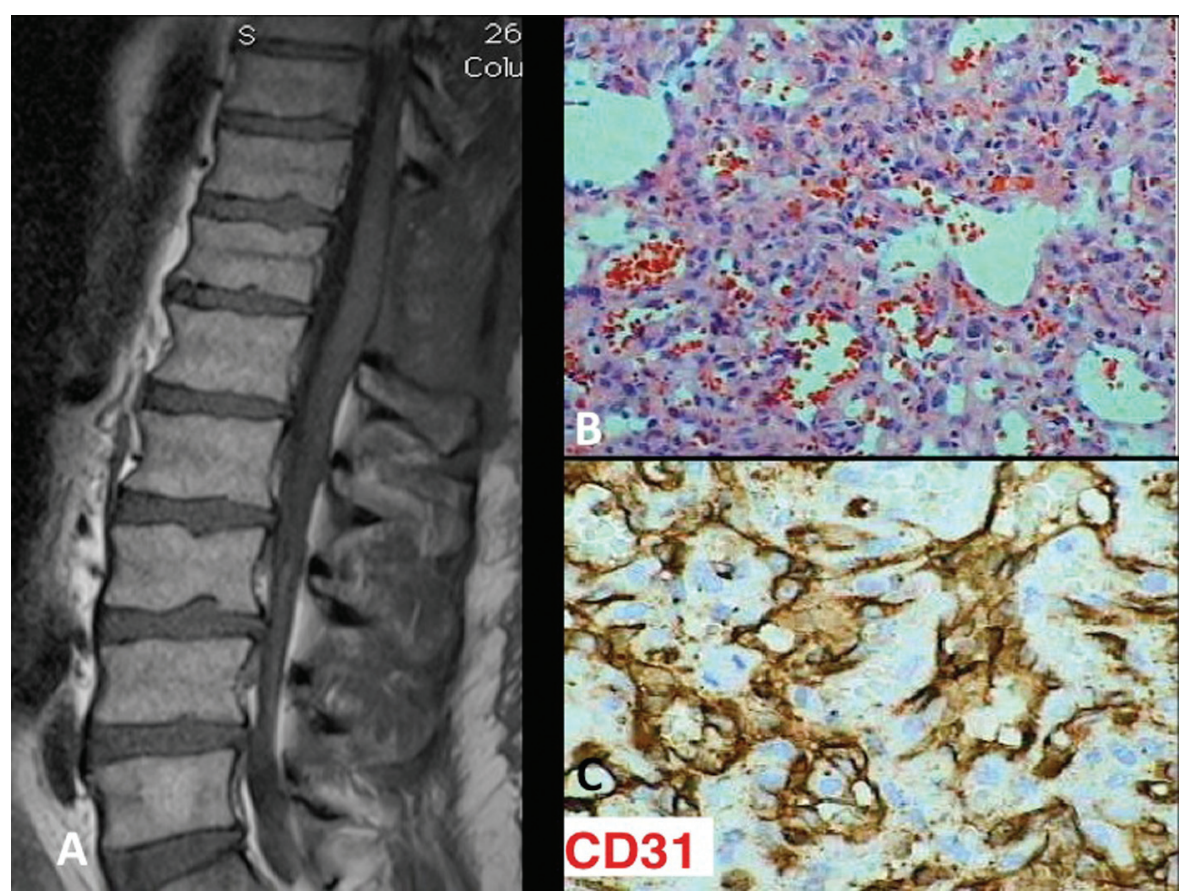

Fig. 2 (A) MRI of the thoracic spine performed after 6 months revealed no residual lesion. (B) Histopathological diagnosis was compatible with capillary hemangioma. (C) Tumor section with CD31 immunostaining showing positive staining. 
Table 1 Cases previously published (in conus medullaris)

\begin{tabular}{|l|l|l|l|l|l|}
\hline Author/ year & Age & Sex & Symptoms & Treatment & Outcome \\
\hline Mawk et al. $^{5}$ & 7 months & $\mathrm{M}$ & Lower extremity apraxia & Subtotal removal & Recovery at 3 weeks \\
\hline Roncaroli et al. $^{6}$ & 53 & $\mathrm{M}$ & Back and leg pain & Subtotal removal & Little improvement at 1.5 years \\
\hline Roncaroli et al. $^{6}$ & 74 & $\mathrm{M}$ & Lower extremity weakness & Subtotal removal & No improvement at 1 year \\
\hline Andaluz et al. $^{4}$ & 41 & $\mathrm{M}$ & Back pain & Total removal & Good recovery at 6 months \\
\hline
\end{tabular}

complete remove was achieved. Histopathological diagnosis was compatible with capillary hemangioma ( - Fig. 2B, 2C). His postoperative course was uneventful and all symptoms, including bladder dysfunction clearly regressed. MRI of the thoracic spine performed after 6 months revealed no residual lesion (-Fig. 2A).

\section{Discussion}

Capillary hemangiomas are benign tumors that are most often encountered in the skin and soft tissues. ${ }^{3}$ To our knowledge only four cases in conus medullaris have been previously described (- Table 1)..$^{2,4-6}$ Similar to those of common intramedullary tumors, the clinical symptoms of intramedullary capillary hemangiomas are sensory, motor, or sphincter dysfunctions, which eventually appear in the late stages of lesion progression. Furthermore, pain is the most common initial symptom in patients with intramedullary capillary hemangiomas, and the duration of illness is usually longer ( $>6$ months) than intramedullary gliomas. ${ }^{1}$ The main differential diagnosis is cavernous angiomas. Capillary hemangiomas usually present with slowly progressive worsening of symptoms, while cavernous angiomas are often associated with acute neurological deterioration due to bleeding. ${ }^{1,3}$

The treatments of intramedullary capillary hemangiomas is very critical in preventing unnecessary morbidity, providing accurate information with respect to prognosis, and establish a regular outpatient follow-up. The natural history of this lesion involving the spinal cord is not well described, although they are common elsewhere in the body. ${ }^{3}$

\section{Conclusion}

The present case suggests that capillary hemangiomas should be considered in the differential diagnosis of a patient with intramedullary spinal vascular lesions. Complete resection using standard micro-neurosurgical techniques is the goal for treatment of intramedullary capillary hemangiomas.

\section{References}

1 Wu L, Deng X, Yang C, Xu Y. Intramedullary spinal capillary hemangiomas: clinical features and surgical outcomes: clinical article. J Neurosurg Spine 2013;19(4):477-484

2 Nowak DA, Widenka DC. Spinal intradural capillary haemangioma: a review. Eur Spine J 2001;10(6):464-472

3 Abe M, Tabuchi K, Tanaka S, et al. Capillary hemangioma of the central nervous system. J Neurosurg 2004;101(1):73-81

4 Andaluz N, Balko MG, Stanek J, Morgan C, Schwetschenau PR. Lobular capillary hemangioma of the spinal cord: case report and review of the literature. J Neurooncol 2002;56(3):261-264

5 Mawk JR, Leibrock LG, McComb RD, Trembath EJ. Metameric capillary hemangioma producing complete myelographic block in an infant. Case report. J Neurosurg 1987;67(3):456-459

6 Roncaroli F, Scheithauer BW, Krauss WE. Capillary hemangioma of the spinal cord. Report of four cases. J Neurosurg 2000;93(1, Suppl) $148-151$ 